\title{
Phytases and myo-inositol modulate performance, bone mineralization and alter lipid fractions in the serum of broilers
}

\author{
K. Żyła ${ }^{1,4}$, R. Duliński ${ }^{1}$, M. Pierzchalskaa ${ }^{1}$, M. Grabacka ${ }^{1}$, D. Józefiak², and S. Świątkiewicz ${ }^{3}$ \\ ${ }^{1}$ University of Agriculture in Krakow, Department of Food Biotechnology, Balicka 122, 30-149 Kraków, Poland \\ ${ }^{2}$ Poznań University of Life Sciences, Department of Animal Nutrition and Feed Management, \\ Wołyńska 33, 60-637 Poznań, Poland \\ ${ }^{3}$ National Research Institute of Animal Production, Department of Animal Nutrition and Feed Science,
}

32-083 Balice, Poland

KEY WORDS: broilers, phytase, myo-inositol, performance, lipid fractions

Received 1 June 2012

Revised 19 January 2013

Accepted 19 March 2013

\section{${ }^{4}$ Corresponding author:}

e-mail: k.zyla@ur.krakow.pl

\begin{abstract}
Under conditions simulating intestinal digestion in broilers, phytase $B$ was found to free myo-inositol from low non-phytate phosphorus maize-soyabean meal-based and wheat-soyabean meal-based diets, whereas both 3- and 6-phytases A accelerated myo-inositol release only in the presence of phytase $B$. In the feeding experiment, myo-inositol at $1 \mathrm{~g} \cdot \mathrm{kg}^{-1}$ increased the feed intake and body weight gain of broilers fed both types of feeds. Phytase B at 1300 acid phosphatase units (AcPU) $\cdot \mathrm{kg}^{-1}$ enhanced feed consumption, body weight gain, and tibia mineralization, whereas phytase $\mathrm{B}$ mixed with 6-phytase A at 500 phytase units (FTU) $\cdot \mathrm{kg}^{-1}$ produced further enhancements in performance and bone mineralization. After 6 weeks, broilers fed the maize-based diets supplemented with both phytase B and 6-phytase A had increased serum concentrations of triglycerides and HDL-cholesterol, as well as an enhanced HDL/total cholesterol ratio. The increases in this ratio cannot be attributed to the release of phosphorus or to the generation of myoinositol by the supplemented enzymes, but can only be explained as effects of intermediate products of phytate dephosphorylation.
\end{abstract}

\section{Introduction}

The physiological effects of exogenous commercial phytases in poultry are related directly to improved absorption and reduced endogenous losses of nutrients (Pirgozliev et al., 2012), but are also likely to extend far beyond these phenomena. In broilers, phytase A added in varying doses (50012500 phytase units (FTU) $\cdot \mathrm{kg}^{-1}$ ) to feeds alleviates the detrimental effects of phytate on performance, on phosphorus, protein and amino acid digestibility, on the activities of intestinal amylase, disaccharidases, and $\mathrm{Na}^{+} \mathrm{K}^{+}$-ATPase, as well as contributes to the elevation of hepatic carotenoid, $\alpha$-tocopherol, retinol, and coenzyme $\mathrm{Q}_{10}$ concentrations (Karadas et al., 2008; Liu et al., 2008). The enzyme also increases the sensitivity of the broiler liver insulin receptor and inhibits the expression of the insulin-like growth factor 1 gene (Józefiak et al., 2010). Moreover, in healthy broilers, phytase A increased the proliferation of blood lymphocytes and intestinal IgA levels, blood T-helper and cytotoxic T cells (Liu et al., 2008). Interestingly, most of these effects have been attributed to the biological activity of lower inositol phosphates, the concentrations of which increase in the intestine as a result of enzymatic hydrolysis of phytate. Myo-inositol, the final 
product of phytate dephosphorylation, has been studied by our team as a feed supplement in both broilers (Żyła et al., 2004) and laying hens (Żyła et al., 2012). When added as a pure substance at $1 \mathrm{~g} \cdot \mathrm{kg}^{-1}$, this compound improved growth performance in broilers, but suppressed laying performance in hens. Due to differences in substrate specificity, commercial preparations of phytases used in poultry nutrition offer multiple pathways of phytate dephosphorylation that may generate distinct pools of lower inositol phosphates. The enzyme, 3-phytase A, such as Natuphos ${ }^{\circledR}$ (BASF, Germany), produced by an Aspergillus niger strain carrying phyA genes from Aspergillus ficuum, initiates phytate hydrolysis by removing the phosphate residue (iP) from position 3 of the myo-inositol ring, whereas 6-phytases A form another subclass of phytases. The enzymes from a recombinant Aspergillus oryzae strain transformed with the phytase gene of Peniophora lycci (Ronozyme P ${ }^{\circledR}$, DSMNutritional Products, Switzerland) or enzymes from hosts carrying the appA gene from Escherichia coli (Phyzyme XP, Danisco, UK; Quantum phytase, AB Enzymes GmbH, Germany; OptiPhos, JBC, USA) start degradation of phytate by removing iP from position 6 or 4 on the phytic acid molecule (Onyango et al., 2005). In contrast to 3- and 6-phytases A, phytase B is an enzyme with broad substrate specificity, high specific activity, and low optimal $\mathrm{pH}$ (Vats et al., 2005). Phytase B, previously known as non-specific acid phosphatase (EC 3.1.3.2), is currently classified as a histidine acid phytase (HAP). It has been postulated previously that simultaneous application of either phytase A along with phytase B offers an effective means of enhancing phytate dephosphorylation in poultry (Żyła et al., 2000). In contrast to various phytases A, phytase B has not been investigated thoroughly and little information is available about its effects when fed as the sole supplemental enzyme. In previous studies with broilers fed maize-soyabean meal-based diets, phytase B enhanced feed intake, body weight gain (BWG), retention of toe ash and $\mathrm{P}$, but not that of Ca (Żyła et al., 2004).

The objective of this study was to determine the influence on feed intake, BWG, and bone mineralization of supplemental myo-inositol, phytase $\mathrm{B}$ alone, and phytase B combined with 6-phytase A added to NPP-deficient maize-based (M) and wheatbased (W) diets. In the second experimental period, the study was also aimed at evaluating the possible influences of dietary supplements on the blood lipid fractions of chickens fed maize-based diets. The potential effects of pure myo-inositol were contrasted with the effects of enzymes, the actions of which may produce inositol in the birds' intestine. In addition to the feeding experiment, the myo-inositol concentrations released from diets $\mathrm{M}$ and $\mathrm{W}$ by 6-phytase A, phytase B, and both enzymes were determined using a model that simulates digestion in different parts of the bird intestine and the HPAECPAD method of myo-inositol quantification.

\section{Material and methods}

\section{Enzyme activity measurements and units}

Two enzyme preparations were used: phytase B (from Finase AP, with a declared activity of 225,000 units $\cdot \mathrm{g}^{-1}$ from AB Enzymes OY, Rajamäki, Finland) and 6-phytase A (from Ronozyme PM with a declared activity of $20 \mathrm{kFTU} \cdot \mathrm{g}^{-1}$ donated by the manufacturer, Hoffman la Roche, Switzerland). One unit of phytase B-acid phosphatase activity (AcPU) is equal to $1 \mu \mathrm{M} \cdot \min ^{-1}$ of $\mathrm{p}$-nitrophenol liberated from $5.5 \mathrm{mM}$ disodium p-nitrophenylphosphate at $40^{\circ} \mathrm{C}, \mathrm{pH} 4.5$. One unit of phytase A activity (FTU) is defined as the quantity of enzyme that liberates $1 \mu \mathrm{M}$ of inorganic $\mathrm{P}$ from $2 \mathrm{mM}$ sodium phytate in $1 \mathrm{~min}$ at $40^{\circ} \mathrm{C}, \mathrm{pH} 4.5$. The activities of phytase and acid phosphatase were determined using previously described procedures (Żyła et al., 2012); the units of enzymatic activity used in the current study are the same as in the cited work.

\section{In vitro digestions and dialyzable inositol}

The in vitro procedure of Żyła et al. (2000) that simulates digestion in the intestinal tract of broilers was used. Determinations of inositol in the dialysates of maize- and wheat-based starter diet samples subjected to the procedure of multiple digestions were performed using high performance anion exchange chromatography with pulsed amperometric detection (HPAEC-PAD) as described previously (Duliński et al., 2011).

\section{Experimental design, birds, diet composition and preparation}

The influence of dietary additives and cereal components was determined in a 2-by-5 factorial completely randomized design from day 1 to 21 . The dietary supplements included myo-inositol at $1 \mathrm{~g} \cdot \mathrm{kg}^{-1}$, phytase B at $1300 \mathrm{AcPU} \cdot \mathrm{kg}^{-1}$, phytase $\mathrm{B}$ enriched in 6-phytase A at $500 \mathrm{FTU} \cdot \mathrm{kg}^{-1}$, or $1.8 \mathrm{~g}$ of monocalcium phosphate added to low nonphytate phosphorus (NPP) diets, either maize-based or wheat-based. For the second experimental period (days 22 to 42), chickens fed the wheat-based diets were removed from the experiment so that the experiment proceeded only with broilers fed the low NPP, maize-based, grower type diets. The experi- 
mental protocol was approved by the Local Bioethics Committee for Experiments with Animals in Krakow (Poland).

Four hundred male one-day-old Ross broiler chickens were purchased from a commercial hatchery and allotted randomly to stainless steel battery brooders with wire-mesh floors. The temperature was maintained at $32^{\circ} \pm 1^{\circ} \mathrm{C}$ in the first 3 days, and was thereafter gradually reduced according to normal management practices. Lighting was continuous and feed and water were provided ad libitum. The experimental design consisted of ten dietary treatments with five replicates of eight birds allotted ran-

Table 1. Composition and nutrient content of the negative control (NC), maize-based (M) and wheat-based (W) diets fed to growing broilers ${ }^{1}, \mathrm{~g} \cdot \mathrm{kg}^{-1}$

\begin{tabular}{|c|c|c|c|}
\hline \multirow[b]{2}{*}{ Indices } & \multicolumn{3}{|c|}{ Basal diets } \\
\hline & $\begin{array}{l}\mathrm{NCM} \\
\text {-starter }\end{array}$ & $\begin{array}{l}\text { NCW } \\
\text {-starter }\end{array}$ & $\begin{array}{l}\text { NCM } \\
\text {-grower }\end{array}$ \\
\hline \multicolumn{4}{|l|}{ Ingredient } \\
\hline maize & 60.03 & - & 63.77 \\
\hline wheat & - & 62.07 & - \\
\hline soyabean meal & 36.00 & 31.90 & 31.00 \\
\hline limestone & 1.00 & 1.00 & 1.00 \\
\hline rapeseed oil & 1.80 & 3.80 & 3.00 \\
\hline $\mathrm{NaCl}$ & 0.30 & 0.30 & 0.30 \\
\hline DL-methionine & 0.22 & 0.24 & 0.22 \\
\hline Lys-HCl & 0.15 & 0.19 & 0.21 \\
\hline vitamin and mineral premix ${ }^{2}$ & 0.50 & 0.50 & 0.50 \\
\hline \multicolumn{4}{|c|}{ Calculated composition, per kg of feed; on an as-is basis } \\
\hline metabolizable energy, MJ & 12.75 & 12.75 & 13.10 \\
\hline crude protein, $\mathrm{g}$ & 225 & 225 & 205 \\
\hline NPP, $g$ & 1.45 & 1.50 & 0.95 \\
\hline lysine, $g$ & 12.0 & 12.0 & 11.50 \\
\hline methionine + cystine, $\mathrm{g}$ & 9.10 & 9.10 & 8.20 \\
\hline Ca analysed, $\mathrm{g}$ & 5.16 & 5.53 & 5.27 \\
\hline P total analysed, $\mathrm{g}$ & 3.56 & 4.06 & 3.38 \\
\hline
\end{tabular}

${ }^{1}$ Four experimental diets were prepared based on each $\mathrm{NCM}$ and NCW formulae: internal control diets (IC): $\mathrm{NC}+1.80 \mathrm{~g}$ of monocalcium phosphate per kg; myo-inositol supplemented diets (Inos): NC $+1 \mathrm{~g}$ of myo-inositol per kg; phytase B supplemented diets (Phy B): NC + phytase B $1300 \mathrm{AcPU}$; (from Finase AP); phytase B (1300 AcPU $\cdot \mathrm{kg}^{-1}$ ) and 6-phytase A $300 \mathrm{FTU} \cdot \mathrm{kg}^{-1}$ ) supplemented diets (from Ronozyme PM). For definitions of an enzymatic activity units (AcPU, FTU) see Material and methods. Dietary ingredients were added at the expense of maize and the metabolizable energy was adjusted by increasing amounts of the vegetable oil

${ }^{2}$ The premix provided, per $1 \mathrm{~kg}$ of starter diet: IU: retinyl acetate 13500, cholecalciferol 3500; mg: tocopheryl acetate 45, menadione sodium bisulfite 3 , thiamin mononitrate 3.25 , riboflavin 7.5 , pyridoxine 5 , cyanocobalamin 0.0325 , biotin 0.15 , Ca-pantothenate 15 , niacin 45 , folic acid 1.5 , choline chloride 600 , manganese 100 , zinc 75 , iron 67.5 , copper 17.5 , iodine 1 , selenium 0.275 , cobalt 0.4 ; per $1 \mathrm{~kg}$ of grower diet; IU: retinyl acetate 12000 , cholecalciferol 3250 , tocopheryl acetate; mg: 40 menadione sodium bisulfite 2.25 , thiamin mononitrate 2, riboflavin 7.25 , pyridoxine 4.25 , cyanocobalamin 0.03 , biotin 0.1 , Ca-pantothenate 12. niacin 40, folic acid 1.0, choline chloride 450 , manganese 100 , zinc 65 , iron 65 , copper 15 , iodine 0.8 , selenium 0.25 , cobalt 0.4 domly to each dietary treatment from day 1 to 21 .

The detailed composition of the basal experimental diets is given in Table 1. The five experimental starter diets based on the NCM formula were: 1) a negative control diet (NC);2) an internal control diet, $\mathrm{NC}+1.8 \mathrm{~g} \cdot \mathrm{kg}^{-1}$ of monocalcium phosphate (IC); 3) $\mathrm{NC}+1 \mathrm{~g} \cdot \mathrm{kg}^{-1}$ of myo-inositol (Inos); 4) $\mathrm{NC}+$ phytase $\mathrm{B}$ at $1300 \mathrm{AcPU} \cdot \mathrm{kg}^{-1}$ (Phy B); 5) $\mathrm{NC}+$ phytase B at $1300 \mathrm{AcPU} \cdot \mathrm{kg}^{-1}$ +6 -phytase A at $500 \mathrm{FTU} \cdot \mathrm{kg}^{-1}$ (Phy A+B). Five (6-10) starter wheat-based diets were formulated according to the same design but the wheat-based IC diet was supplemented with $1.57 \mathrm{~g} \cdot \mathrm{kg}^{-1}$ of monocalcium phosphate. The NPP levels of the IC diets were established experimentally and were equivalent to the NPP concentrations in the Phy A+B diets. The quantity of NPP released from the diets by phytases was determined in vitro by the procedure described previously (Żyła et al., 2000). All starter diets were isonitrogenous and isocaloric (Table 1). The grower-type, low NPP maize-based experimental diets were formulated using the same design. The diets were prepared in mash form. Powdered enzymes were premixed with a small quantity of feed and added to the remaining part of a diet during final mixing. The protein and energy contribution from enzyme addition was considered insignificant. During the course of the experiment all of the diets were stored in a cooler at $4^{\circ} \mathrm{C}$.

\section{Sample collection and assays}

At the end of week 3 of the experiment, chickens were deprived of feed for 6 hours, weighed individually and feed consumption was determined for each pen. Mortality was recorded in each treatment during the first experimental period. On completion of the experiment the chickens were weighed, killed by cervical dislocation and decapitated. Samples of blood from 12 birds from each treatment group were collected into serum tubes (Greiner Bio-One $\mathrm{GmbH}$, Austria). Analysis of serum lipid profiles was performed using an automatic biochemical analyzer Metrolab 2300 (Argentina). Total cholesterol, triglycerides, and lipoprotein HDL and LDL fractions were assessed quantitatively by an enzymatic method using reagent sets from

Pointe Scientific, Inc. (MI, USA). Samples of toes were obtained from twelve birds in each treatment by carefully and uniformly severing the middle toe from each foot between the second and third tarsal bones. The samples were dried at $100^{\circ} \mathrm{C}$ for $24 \mathrm{~h}$, weighed and dry-ashed at $600^{\circ} \mathrm{C}$ overnight for determination of toe ash. The phosphorus concentration in feed samples was determined colorimetrically by the molybdo-vanadate method (AOAC, 1995). Calcium concentrations in feed samples were determined by flame atomic absorption spectrophotometry (Spectrometer AA 240FS, Varian). 


\section{Statistical analyses}

The experimental data were analyzed by the General Linear Models Procedure of Statgraphics Plus for Windows (1996) using the one-way and two-way ANOVA models. Mean differences were determined using Fisher's least significant difference test. Mortality in each treatment was expressed in percentages and subjected to arcsin transformation to ensure homogeneity of variations. Statistical significance was accepted at $\mathrm{P}<0.05$.

\section{Results}

The concentrations of myo-inositol released from maize- and wheat-based starter diets supplemented with phytase B and 3- or 6-phytase A and subjected to the in vitro procedure of multiple digestions, analyzed by the HPAEC-PAD technique, are presented in Figure 1. The type of cereal was a decisive factor affecting the efficacy of phytases in the release of myo-inositol. The quantities of myo-inositol found in the digesta of wheat-based diets were significantly higher than those found in maize-based feeds. Furthermore, phytase B tested as a single feed supplement was highly effective at 1 ACPU $\cdot \mathrm{g}^{-1}$ in wheat-based diets, but was ineffective in the maize-based ones. Both 3- and 6-phytases A tested at a constant level of $500 \mathrm{FTU} \cdot \mathrm{kg}^{-1}$ enhanced myo-inositol release from both types of diets. The highest quantities of myo-inositol (around $1100 \mu \mathrm{g} \cdot \mathrm{g}^{-1}$ ) were released from wheat-based diets by either 1 AcPU of phytase B $\cdot \mathrm{g}^{-1}$ and 500 FTU of 3-phytase $\mathrm{A} \cdot \mathrm{kg}^{-1}$ or by $2 \mathrm{AcPU}$ of phytase $\mathrm{B} \cdot \mathrm{g}^{-1}$ accompanied by $500 \mathrm{FTU} \cdot \mathrm{kg}^{-1}$ of 6-phytase A.

In the feeding trial, significant main effects of dietary additions and the type of cereal fed, with no

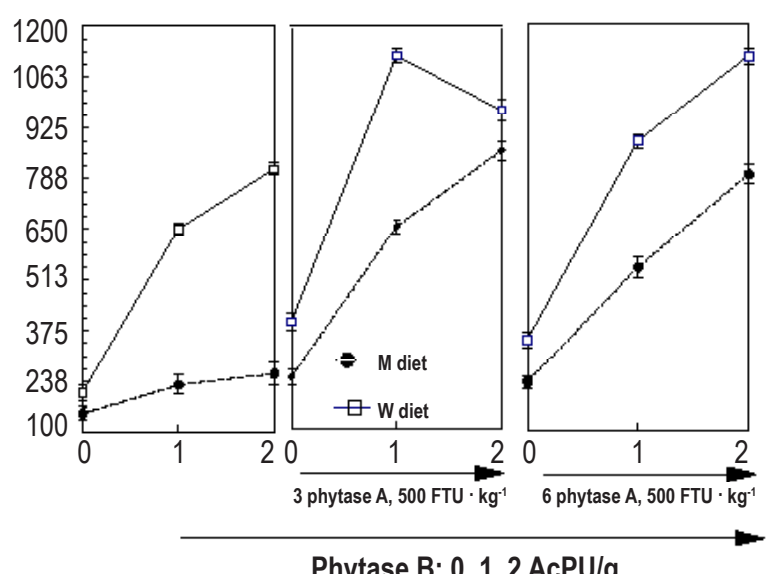

Figure 1. The influence of the type of phytase on the release of myo-inositol from samples of the maize-based ( $M,-\bullet-)$ and wheat-based (W, - --) starter diets. Samples of diets were digested by the three-step in vitro method (Żyła et al., 2000) and dialyzed digesta were analysed for the myo-inositol by the HPAECPAD technique as described previously (Duliński et al., 2011)
Table 2. Main effects of dietary additives and type of diet (maizebased or wheat-based) on performance of broilers, 1-21 day of age ${ }^{1,2}$

\begin{tabular}{lllll}
\hline Main effect & $\begin{array}{l}\text { Feed } \\
\text { intake, g }\end{array}$ & $\begin{array}{l}\text { Body } \\
\text { weight } \\
\text { gain, g }\end{array}$ & $\begin{array}{l}\text { Feed } \\
\text { conversion } \\
\text { ratio, g }\end{array}$ & $\begin{array}{l}\text { Mortality, } \\
\text { arcsin, \% }\end{array}$ \\
\hline $\begin{array}{l}\text { Dietary additives } \\
\text { NC }\end{array}$ & $565^{\mathrm{c}}$ & $263.4^{\mathrm{c}}$ & $2.195^{\mathrm{a}}$ & 2.244 \\
IC & $633^{\mathrm{b}}$ & $321.0^{\mathrm{b}}$ & $2.005^{\mathrm{b}}$ & 3.142 \\
Inos & $617^{\mathrm{b}}$ & $320.9^{\mathrm{b}}$ & $1.977^{\mathrm{b}}$ & 3.598 \\
Phy B & $652^{\mathrm{ab}}$ & $345.1^{\mathrm{ab}}$ & $1.918^{\mathrm{b}}$ & 2.244 \\
Phy A+B & $692^{\mathrm{a}}$ & $371.1^{\mathrm{a}}$ & $1.908^{\mathrm{b}}$ & 1.795 \\
Type of diet & & & & \\
maize & 621 & $295^{\mathrm{B}}$ & $2.156^{\mathrm{A}}$ & $3.773^{\mathrm{A}}$ \\
$\quad$ wheat & 643 & $354^{\mathrm{A}}$ & $1.842^{\mathrm{B}}$ & $1.436^{\mathrm{B}}$ \\
$\begin{array}{l}\text { Pooled SEM } \\
\text { Probability }\end{array}$ & 12 & 15.6 & 0.059 & 0.554 \\
dietary additives & 0.001 & 0.001 & 0.007 & $\mathrm{NS}$ \\
$\begin{array}{c}\text { cereal } \\
\text { interaction }\end{array}$ & $\mathrm{NS}$ & 0.001 & 0.001 & 0.004 \\
\hline
\end{tabular}

$\mathrm{NC}$ - negative control diet, IC - internal control diet $\left(\mathrm{NC}+1,8 \mathrm{~g} \cdot \mathrm{kg}^{-1}\right.$ monocalcium phosphate. ${ }^{\mathrm{a}-\mathrm{b}}$ means within a column with no common superscript differ significantly $(\mathrm{P}<0.05)$; ${ }^{1}$ for experimental diets formulation see Table $1 ;{ }^{2}$ the values are the means of 5 replicates of 8 birds each

interactions between experimental factors, were observed for body weight gain and FCR in the first experimental period. Feed intake did not depend on the cereal component of the diet, whereas mortality was significantly higher in broilers fed diets based on maize but was not altered by the tested dietary additions (Table 2). The highest feed intakes were recorded in broilers fed the diets supplemented with both phytases, while the lowest feed consumption was recorded in birds fed the NC diet. Feed intakes were significantly improved in broilers fed diets supplemented with either myo-inositol or monocalcium phosphate. The addition of phytase B brought FI to values that did not significantly differ from those observed in birds fed diets supplemented with both phytases. Generally, the variations in BW paralleled the changes in feed intake, but the gains were clearly higher in broilers fed the wheat-based diets. With the exception of the NC diet, FCR did not differ among dietary treatments but, again, in comparison with the maize-based diets, the FCR values for wheat-based diets were significantly improved.

At week 6, broilers fed the maize-based diets had final body weights that significantly depended on the dietary additives tested (Table 3 ). The highest body weights were recorded in chickens fed diets supplemented with phytase B and phytase A, whereas the lowest body weights were observed in their counterparts fed the NC diet. Similarly to the first experimental period, the addition of either phytase B or monocalcium phosphate improved body weight as compared with the NC treatment. Supplemen- 
tary myo-inositol only numerically enhanced BWG above the level that was characteristic for birds fed the $\mathrm{NC}$ diet, but the value did not differ significantly from the values observed in the IC and Phy B treatments. Broilers that were fed the NC diet had poor bone mineralization, as evidenced by the low percentage of ash in the toes. The highest percentages of ash were found in the toes collected from broilers fed the diets supplemented with phytases A and B. Bone mineralization was also positively altered by phytase B used as a sole supplemented enzyme. In broilers fed the diets supplemented with monocalcium phosphate or myo-inositol, the percentage of toe ash was only numerically increased and did not differ significantly from that determined for birds fed the NC diet.

The dietary supplements tested in the current study significantly modulated the serum lipid profiles in experimental chickens (Table 3). Serum triglyceride concentrations were in the range from 22.1 $\mathrm{mg} \cdot \mathrm{dl}^{-1}$ to $67.3 \mathrm{mg} \cdot \mathrm{dl}^{-1}$ for broilers fed the negative control diet and the diet containing two phytases, respectively. The variations observed among mean values of this parameter were somehow connected to the changes in the final body weight and showed a similar pattern of variability. The serum HDL cholesterol concentrations were similar in chickens fed the different diets, with the exception of broilers fed the diets supplemented with both phytases, who had significantly higher HDL levels. Furthermore, broilers that received both phytases had the highest HDL-to-total cholesterol ratio as opposed to birds fed the IC diet, whose serum HDL-to-total cholesterol ratios were the lowest among all of the experimental birds. Myo-inositol and phytase B applied as a single feed supplement affected the HDL-to-total cholesterol ratio similarly and led to intermediate values of this index.

Table 3. Effects of dietary additives on the final body weight (FBW), toe ash, and concentration of triglycerides and HDL cholesterol in 42day old broilers fed the maize-based starter and grower diets ${ }^{1}$

\begin{tabular}{|c|c|c|c|c|c|}
\hline \multirow[b]{2}{*}{ Treatment } & \multirow[b]{2}{*}{$\begin{array}{l}\text { FBW } \\
n=80 \\
g\end{array}$} & \multirow[b]{2}{*}{$\begin{array}{l}\text { Toe ash } \\
\mathrm{n}=12, \\
\%\end{array}$} & \multicolumn{3}{|c|}{ Serum, $n=12$} \\
\hline & & & $\begin{array}{l}\text { triglycer- } \\
\text { lides, } \\
\mathrm{mg} \cdot \mathrm{dl}^{-1}\end{array}$ & $\mathrm{HDL}$ & $\begin{array}{l}\text { HDL/total } \\
\text { cholesterol }\end{array}$ \\
\hline $\mathrm{NC}$ & $1366^{c}$ & $10.7^{c}$ & $22.1^{\mathrm{c}}$ & $111.0^{b}$ & $0.647^{b c}$ \\
\hline IC & $1611^{\mathrm{b}}$ & $11.2^{c}$ & $33.2^{\mathrm{b}}$ & $109.2^{b}$ & $0.585^{c}$ \\
\hline Inos & $1495^{\mathrm{bc}}$ & $11.7^{\mathrm{bc}}$ & $23.8^{b c}$ & $115.5^{b}$ & $0.679^{b}$ \\
\hline Phy B & $1622^{b}$ & $12.7^{b}$ & $26.4^{b}$ & $117.5^{b}$ & $0.706^{b}$ \\
\hline PhyA+B & $1968^{a}$ & $14.2^{\mathrm{a}}$ & $67.3^{\mathrm{a}}$ & $156.5^{\mathrm{a}}$ & $0.826^{a}$ \\
\hline SEM & 82 & 0.45 & 4.85 & 7.13 & 0.0279 \\
\hline$P$ & 0.001 & 0.001 & 0.001 & 0.001 & 0.001 \\
\hline
\end{tabular}

${ }^{1}$ for experimental diets formulation see Table 1 ; ${ }^{\text {a-c; } A-B}$ means within a column with no common superscript differ significantly $(P<0.05)$. $\mathrm{NC}, \mathrm{IC}$ - see table 2

\section{Discussion}

In this study, phytase B proved again to be the key catalyst that is necessary to generate myo-inositol from phytates. In contrast to the experimental evidence provided in a previous study that showed the ability of the enzyme to generate inositol from a sodium phytate solution (Żyła et al., 2012), here we document its ability to free substantial quantities of this substance from fully formulated maize-based and wheat-based diets under conditions that mimic digestion in the intestine of birds. Furthermore, the much higher efficacy of phytase B in wheatbased than in maize-based diets points to possible cooperation of the supplemental microbial enzyme with endogenous phytate-degrading enzymes from wheat. This can be attributed to the much higher content of endogenous phytate-degrading enzymes in wheat than in maize (Eeckhout and De Paepe, 1994; Viveros et al., 2000).

The much higher activity of endogenous phytate-degrading enzymes in wheat also explains the generally better performance of broilers fed the wheat-based diets as compared with birds fed the maize-based diets. This well-known phenomenon that is responsible for better phosphorus availability from wheat than from maize resulted in a higher BWG, better FCR, and lower mortality rate in chickens fed the starter diets based on wheat. It seems interesting to note that, in contrast to the in vitro part of this study, there were no data suggesting cooperation between endogenous and supplemental phytases in the broiler feeding experiment, since the interactions between dietary additives and the cereal components of the diets were not significant for any of the parameters studied.

In contrast to phytase $\mathrm{B}$, which affected broiler performance consistently throughout both experimental periods, supplemental myo-inositol stimulated the growth of chickens more efficiently in the starter than in the grower period. Myo-inositol has already been reported to enhance body weight gains in growing broilers (Żyła et al., 2004), thus the current study provides yet more evidence of the growth-stimulating effect of this compound in broilers. Furthermore, the study broadens the previous findings and extends them to wheat-based diets. It also suggests that the biological activity of myo-inositol may be restricted to the early stages of bird development, or that the supplementation level of $1 \mathrm{~g} \cdot \mathrm{kg}^{-1}$ diet may be too low.

The experimental design employed in this study included the IC diet formulated to contain amounts of available phosphorus similar to those for the Phy 
$\mathrm{A}+\mathrm{B}$ diet. The significant differences found between these two experimental groups could, therefore, be attributed to factors other than the increase in the concentration of available phosphorus resulting from enzymatic dephosphorylation. Further contrasting of the effects against the diet supplemented with myo-inositol may clearly point to the involvement of lower myo-inositol phosphates, the generation of which is accelerated by the joint action of phytases A and B on feed phytates (Żyła et al., 2000). Furthermore, in the diet containing both phytases, myo-inositol, which is also freed from phytate as evidenced by the in vitro part of the study, may interact with its lower phosphate esters creating a unique environment of 'enzymatically generated inositol'. In this study, broilers that were fed the diet supplemented with phytase A and B not only consumed more feed, had higher weight gains at days 21 and 42, but also had higher percentages of ash in the toes than chickens fed the IC diet. This suggest the interaction of compounds other than phosphorus or myo-inositol in bone mineralization and may reflect the well-known involvement of myo-inositol triphosphates in the calcium signaling pathway (Suzuki et al., 2010). Indeed, phytase B alone and, to a much higher extent, in combination with 6-phytase A not only enhanced bone mineralization, but also increased body weight gains in broilers fed the NPP- and Ca-deficient diets, emphasizing the important role that phytases play in Ca metabolism.

The possible impact of different feed supplements on the serum lipid profile of broilers has not attracted much attention in recent research. Moreover, some of the findings about the impact of dietary $\omega-3$ unsaturated fatty acids on the serum lipid profiles of birds are inconsistent (Szymczyk et al., 2001; Atakisi et al., 2009). Liu et al. (2010) have documented the effects of phytate and phytase on intestinal lipase activity and lipid metabolism in broiler chickens. The addition of sodium phytate (Liu et al., 2010) or chitosan (Razdan and Pettersson, 1994) to diets for broiler chickens produced significant decreases in the plasma concentration of total cholesterol and a concomitant increase in the HDL-to-total cholesterol ratio. This was probably caused by enhanced reversed cholesterol transport in response to the intestinal loses of the dietary lipids that interacted with phytate or chitosan during digestion. This explanation, however, cannot be offered for the significant reduction in total plasma cholesterol of broilers consuming diets enriched in a microbial culture of mixed Lactobacillus strains as reported by Kalavathy et al. (2003). From among all of the experimental birds tested in our study, broil- ers fed the diets supplemented with phytase A and $B$ had the highest HDL cholesterol contents and the highest HDL-to-total cholesterol ratios. Zamudio et al. (2001) reported not only high levels of phytate-degrading enzymes in six Lactobacillus strains, but also pointed out that the enzymes were a type of non-specific acid phosphatase, whose catalytical properties resemble the phytase B tested in our study. It seems, therefore, that among the products generated by phytase from phytate there must have been compounds with the ability to modulate lipid metabolism in broilers. Taking into account the results of the study presented here, neither myo-inositol nor free phosphorus can be candidates for this role, thus the single remaining possibility is the myo-inositol phosphate intermediates generated by the concerted action of 6-phytase A and phytase B.

\section{Conclusions}

Myo-inositol fed at $1 \mathrm{~g} \cdot \mathrm{kg}^{-1}$ was found to stimulate the growth of broilers fed both maize-based and wheat-based diets at week 3 . At week 6 , however, it did not significantly affect the toe ash content in birds fed the maize-based diets. At week 3, phytase $\mathrm{B}$ fed at $1300 \mathrm{AcPU} \cdot \mathrm{kg}^{-1}$ enhanced performance parameters in broilers fed maize- and wheat-based diets, whereas 6-phytase A added to feeds (500 FTU $\cdot \mathrm{kg}^{-1}$ ) on top of phytase B produced further enhancements in these parameters. At week 6, both phytases increased the toe ash of chickens fed the maize-based diets. Broilers fed the maize-based diets supplemented with both phytase B and 6-phytase A for 6 weeks had increased concentrations of serum triglycerides and HDL-cholesterol, as well as an enhanced HDL-to-total cholesterol ratio.

\section{Acknowledgment}

Supported by Ministry of Science and Higher Education, Grant No N N311 307736.

\section{References}

AOAC, 1995. 4. Association of Official Analytical Chemists. Animal feeds. Phosphorus. 965.17 Photometric method. Page 27 in: Official Methods of Analysis. 16 Edition. Washington, DC

Atakisi E., Atakisi O., Yaman H. Arslan I., 2009. Omega-3 fatty acid application reduces yolk and plasma cholesterol levels in Japanese quails. Food Chem. Toxicol. 47, 2590-2593

Duliński R., Starzyńska-Janiszewska A., Stodolak B., Żyła K., 2011. Comparison of high-performance ion chromatography technique with microbiological assay of myo-inositol in plant components of poultry feeds. J. Anim. Feed Sci. 20, 143-156

Eeckhout W., De Paepe M., 1994. Total phosphorus, phytate phosphorus and phytase activity in plant feedstuffs. Anim. Feed Sci. Tech. 47,19-29 
Józefiak D., Ptak A., Kaczmarek S., Maćkowiak P., Sassek M., Slominski B.A., 2010. Multi-carbohydrase and phytase supplementation improves growth performance and liver insulin receptor sensitivity in broiler chickens fed diets containing full-fat rapeseed. Poultry Sci. 89, 1939-1946

Kalavathy R., Abdullah N., Jalaludin S., Ho Y.W., 2003. Effects of Lactobacillus cultures on growth performance, abdominal fat deposition, serum lipids and weight of organs of broiler chickens. Brit. Poultry Sci. 44, 139-144

Karadas F., Pirgozliev V., Pappas A.C., Acamovic T., Bedford M.R., 2008. Effects of different dietary phytase activities on the concentration of antioxidants in the liver of growing broilers. J. Anim. Physiol. Anim. Nutr. 94, 519-526

Liu N., Ru Y.J., Li F.D., Cowieson A.J., 2008. Effect of diet containing phytate and phytase on the activity and messenger ribonucleic acid expression in chickens. J. Anim. Sci. 86, 3432-3439

Liu N., Ru Y.J., Wang J., Xu T., 2010. Effect of dietary sodium phytate and microbial phytase on the lipase activity and lipid metabolizm of broiler chickens. Brit. J. Nutr. 103, 862-868

Onyango E. M., Bedford M.R., Adeola O., 2005 Efficacy of an evolved Escherichia coli phytase in diets of broiler chicks. Poultry Sci. $84,248-255$

Pirgozliev V., Bedford M.R., Oduguwa O., Acamovic T., Allymehr M., 2012. The effect of supplementary bacterial phytase on dietary metabolisable energy, nutrient retention and endogenous losses in precision fed broiler chickens. J. Anim. Physiol. Anim. Nutr. 96, 52-57

Razdan A., Pettersson D., 1994. Effect of chitin and chitosan on nutrient digestibility and plasma lipid concentrations in broiler chickens. Brit. J. Nutr. 72, 277-288

Statgraphics Plus for Windows, 1996. Advanced regression. Manugistics, Inc. Rockville, MA

Suzuki T., Nishioka T., Ishizuka S., Hara H., 2010. A novel mechanizm underlying phytate-mediated biological action-phytate hydrolysates indu ce intracellular calcium signaling by a Gaq protein-coupled receptor and phospholipase C-dependent mechanism in colorectal cancer cells. Mol. Nutr. Food Res. 54, 947-955

Szymczyk B., Pisulewski P.M., Szczurek W., Hanczakowski P., 2001. Effects of conjugated linoleic acid on growth performance, feed conversion efficiency, and subsequent carcass quality in broiler chickens. Brit. J. Nutr. 85, 465-473

Vats P., Bhattacharyya M., Banerjee U.C., 2005. Use of phytases (myo-inositolhexakisphosphate phosphohydrolases) for combating environmental pollution: A biological approach. Crit. Rev. Environ. Sci. Technol. 35, 469-486

Viveros A., Centeno C., Brenes A., Canales R., Lozano A., 2000. Phytase and acid phosphatase activities in plant feedstuffs. J. Agr. Food Chem. 48, 4009-4013

Zamudio M., González A., Medina A.J., 2001. Lactobacillus plantarum phytase activity is due to non-specific acid phosphatase. Lett. Appl. Microbiol. 32, 181-184

Żyła K., Koreleski J., Świątkiewicz S., Wikiera A., Kujawski M., Piironen J., Ledoux D.R., 2000. Effects of phosphorolytic and cell walldegrading enzymes on the performance of growing broilers fed wheat-based diets containing different calcium levels. Poultry. Sci. 79, 66-76

Żyła K., Mika M., Stodolak B., Wikiera A., Koreleski J., Świątkiewicz S., 2004. Towards complete dephosphorylation and total conversion of phytases in poultry feeds. Poultry Sci. 83, 1175-1186

Żyła K., Mika M., Duliński R., Koreleski J., Świątkiewicz S., Piironen J., 2012. Effects of inositol, inositol-generating phytase B applied alone, and in combination with 6-phytase A to phosphorus-deficient diets on laying performance, eggshell quality, yolk cholesterol and fatty acids deposition in laying hens. Poultry Sci. 91, 1915-1927 